Blue-headed Vireo*

Black and White Warbler*

Nashville Warbler*

Tennessee Warbler

Northern Parula Warbler*

Cape May Warbler

Yellow Warbler*

Black-throated Blue Warbler*

Myrtle Warbler*

Magnolia Warbler*

Chestnut-sided Warbler*

Bay-breasted Warbler

Black-poll Warbler

Blackburnian Warbler*

Black-throated Green Warbler*

Pine Warbler

Yellow Palm Warbler

Ovenbird*

Water-Thrush*

Maryland Yellow-throat*

Wilson's Warbler
Canada Warbler*

Redstart*

American Pipit

Catbird*

House Wren

Winter Wren*

Short-billed Marsh Wren

Brown Creeper $\dagger$

White-breasted Nuthatch $\dagger$

Red-breasted Nuthatch $\dagger$

Chickadee*

Acadian Chickadee†

Labrador Chickadee

Golden-crowned Kinglet

Ruby-crowned Kinglet

Veery*

Olive-backed Thrush*

Hermit Thrush*

Robin*

Bluebird*

(163 species)

\title{
HOME LIFE OF THE VESPER SPARROW AND THE HERMIT THRUSH.
}

BY E. M. AND W. A. PERRY. ${ }^{1}$

One summer at Douglas Lake, Michigan, the Biological Station of the University of Michigan, we had an opportunity of studying the nesting habits of the Vesper Sparrow and the Hermit Thrush. The results of my observations are presented below.

I.

The Vesper Sparrow.

One usually associates the Vesper Sparrow with large, grassy fields and dusty roadsides. The region in which I made my study 
was of a very different character. It had been cleared of the original forest of pines, and further denuded by forest fires. The ground was still strewn with charred logs and stumps. Here and there a tall, charred skeleton of a tree trunk towered high in the air. The living vegetation consisted of scattered tufts of blue grass; shrubby growths of aspen, huckleberry, sumac, and bracken, and a few taller trees of oak, aspen, and maple. One of the two nests that I observed was quite well hidden by a small blackberry bush, some tall blue grass, and a few brackens; the other was under the drooping branches of a sumac.

Previous to the hatching, I used to visit the nests every day. They were simple structures consisting of shallow basins in the earth, made by the sparrows themselves; a coarse lining of the stems of bracken; and a softer lining of blue grass. Four white, brown-blotched eggs were laid in each nest. Only three of the four eggs hatched in each.

As soon as the first bird began to peck its way out of the shell, I devoted from six to nine hours a day for eight days to observation. I used as a point of vantage a blind, or tent, four feet square, pitched within about thirty inches of the nests under observation. I had cut a slit three or four inches long in the side toward the nests for an observation window, and another, lower down, for the protrusion of the camera lens. I had to avoid making the slightest noise or any movement across the window.

In order to determine the duties of the different sexes, I tried to distinguish the male from the female; but that is not an easy matter when the plumages are practically identical. After a day or two, however, I found that I could differentiate the parents by the shade of the back feathers, or the loss of such prominent ones as the white outer tail feathers. I am not sure that my distinction of the sexes was correct, but I give the results of my observation according to that distinction.

From the first the sparrows were clean nest-keepers. Their work began as soon as the young cast aside the shells. These were not allowed to litter the nest, nor were they scattered carelessly about. They were simply eaten by the parents while at the nest. One parent did take a shell some few feet away from the nest before eating it. The shell seemed brittle and broke into many fine bits. These were all carefully picked up. Ants were numerous and 
were a'ways crawling through the lining and into the nest. I often used to see the parents perched on the nest, with most of the upper part of the body hidden as they searched through the wall for retreating ants. Frequently the wind blew bits of leaves or grass into the nest. These were never allowed to remain. The excreta of the young never soiled the home; it was eaten by the parent as soon as the nestling evacuated it from the cloaca. Consequently the nest looked as clean when the family left as it did the first day of its use.

Another duty of the sparrow parents was that of brooding, The greater amount of this was done by the one I took to be the female. In the second nest neither parent did much brooding, but the male did none. During the hottest part of the day the female, her mouth agape, often stood up in the nest with wings outspread to keep the heat of the sun from the nestlings. While I was observing the first nest, there was a heavy, driving rain storm that lasted nearly two hours. The female did duty then. She brooded facing the storm, the water running off her back in rivulets. She was a drenched bird when the storm decreased and the dry male came to relieve her. The nestlings, however, were perfectly dry.

A third duty was that of feeding the young. The parents were kept busy bringing food on an average of every twenty minutes for the first few days. This interval decreased to ten by the fifth day, and then slightly increased to the seventh day. In the first nest the ratio of feeding was 11: 7 in favor of the female, in the second, it was $2: 1$. The parents brought grasshoppers, crickets, katydids, sawfly larvæ, and some hairy larvæ I could not identify. I rather thought they selected small specimens when the birds were small. At times, however, they brought such large grasshoppers, with legs and wings missing, that the young could swallow them only with much struggling. The parent bird always placed the food well down the throat of the nestling by inserting its own mandible into the mouth. Often the nestling still held its mouth agape after the food had been placed in it and did not seem able to swallow for a few seconds. The mother of one of the families had a difficult task in getting any of the nestlings to swallow a large brown caterpillar. She placed it into mouth after mouth and then tried all 
over again. The larva by this time was torn and dripping. One of the nestlings findly swallowed it in this condition.

A fourth duty had to do with guarding the nest. In order to keep the location of the nest a secret, the parents rarely flew directly to the nest or away from it. Even when they were frightened, they usually took time to hop away a short distance before flying. They approached the nest by comparatively definite routes. They would alight some ten or fifteen feet away. Then they would hop up slowly, stopping now and then on some observation point, such as a stump or fallen log, look around, call "Neen, neen," and then hop up on one particular side of the nest's rim.

All the activities of the parents seemed to be part of a definite routine. This call, "Neen, neen," seemed to be a signal call. If one of the pair was at the nest when the other called, it hurriedly left. Both parents were never found at the nest at the same time during my observation. I have even seen a parent engaged in feeding, leave without completing the task when this call was given by the other. Each parent waited after feeding the nestling for it to mute, and then seizing the excreta, would either swallow it or leave with it in the mandibles. After feeding the nestlings, the parent sometimes brooded until compelled to leave at the call, "Neen, neen." There was no variation in their routine except in the intervals between feedings, a decrease in the amount of time spent in brooding, and the breaking of the schedule caused by storms or other interruptions beyond their control.

One day in the first nest, the brooding female flew directly from the nest. This was such a pronounced breaking of custom that I craned my neck to see what exceptional event could warrant the act. I saw her a few feet away trailing her wings on the ground as if injured. A short distance from her was a garter snake. I could not wait to see the outcome of what seemed like a pending tragedy, but killed the enemy immediately. Realizing that my observations might come to a premature end if another snake should be in search of a dinner while I was absent, I placed around the nest a circular fence of close-meshed wire 18 inches high and about 10 feet in diameter. I then thought that this would keep out snakes. I now doubt its efficiency.

Soon after I had placed this fence around the nest, the male 
approached in the usual manner of hopping toward the nest. When he reached the fence, he ran around it looking for an opening. $\mathrm{He}$ had to do this several times before he felt positive that he could not get through. He then became alarmed, and disappeared from my view for about twenty-four hours. The female was more determined than the male. It took her two hours before she felt convinced that there was no opening. She then flew over. My day was drawing to an end. So I picked up my camera, pocketed my note book, and went home, feeling confident that I had provided against the danger of further snake enemies, and that the female now knew how to reach her young.

The next morning when I came to the nest, I found what I feared was a castastrophe. There lay three cold, limp, apparently lifeless birds. I cast aside the fence and entered my tent, heartsick. The nestlings had been starved and unbrooded all the chill night through. In a little while the female came to the nest and in her efficient manner proceeded with the only sane treatment possible. She brooded in a quiet, untiring way for four uninterrupted hours. Finally hunger drove her forth. Then, still feeling guilty, I looked in and found all three nestlings able to move about. By noon they were again keeping the parent busy bringing food, and since the male did not appear all day, it was a double task for her.

The second family also had a snake visitor that I had to kill. There seems little doubt that many young birds, especially those that live in nests on the ground provide food for snakes. Even after they leave the nest, they are likely to be attacked. I visited the first nest the day after the nestlings left. I had about decided that there was nothing to see but the chirping parents in the nearby trees, when I heard a screaming "Zee, zee," and saw the parents flying about in distress. Hurrying out, I found a nestling held in a snake's jaw. The snake wriggled away, and the bird lost itself in the grass. I felt that the snake would come back. So I waited until I again heard the call. This time I succeeded in killing the snake and in capturing the bird. It had a jagged tear on its thigh where the snake's teeth had held it. I put it in the nest, but it would not stay.

The objects of all this parental care and of much of my interest were hatched blind and entirely naked, with the exception of a row of short down feathers extending from the crown of the head to the 
tail. They were able from the first to raise their large heads on their long, wobbly necks, and open their mouths for food. In fact, they seemed able to do this before the down had scarcely dried. They soon became rather active, ill-mannered, aggressive nestlings, squabbling over their food. Their bodies began to be marked with distinct feather tracts. On the third day the wing pins had broken through the skin. Their eyes began to open about this time, and they could make a faint call. This became a loud "zee, zee" by the sixth day. They no longer remained quietly huddled in the bottom of the nest, but began to assume a definite position, with their heads resting on the rims of the nest, their breasts against the sides, and their claws firmly clasped in the lining. When they raised their heads and opened their mouths, they looked like a bowl of queer flowers. Now and then they stood up and flapped their wings. When they were six days old, they began to preen their bursting feathers. This they did by seizing each feather at the base, and drawing the mandibles over it toward the apex. This helped to remove the dried sheath.

In order to estimate the rapidity of their growth, I weighed them every day. Since they soon became too active to keep on the scale pan, I made a cheese cloth bag to put them in while I weighed them. To distinguish one from another, I marked them with paint on different parts of the body. Having the birds marked also gave me an opportunity of determining if the parents fed them impartially. I decided that they fed indiscriminately. The nestling stretching out its neck the longest, received the most food. In spite of this, however, the following table shows an approximately equal increase in the weight of each of the three.

\section{TABLE I.}

SHOWING WEIGHT IN GRAMS OF NESTLINGS FROM DAY TO DAY.

\begin{tabular}{lcccc}
\multicolumn{1}{c}{ Date } & July 19 & July 20 & July 21 & July 22 \\
Bird I & 2.92 & 4.82 & 7.48 & 9.07 \\
Bird II & 2.85 & 4.76 & 7.23 & 8.87 \\
Bird III & 2.66 & 4.23 & 5.83 & 8.48 \\
$\begin{array}{l}\text { Number of times food } \\
\text { was brought to nest }\end{array}$ & 16 & 23 & 27 & 35 \\
Weather & & & & \\
& Warm & Cool & Cool & Clear \\
& Clear & Cloudy & Cloudy & Cool
\end{tabular}


Table I continued.

\begin{tabular}{|c|c|c|c|c|}
\hline Date & July 23 & July 24 & July 25 & July 26 \\
\hline Bird I & 13.41 & 15.62 & 16.98 & 17.30 \\
\hline Bird II & 13.22 & 14.97 & 16.01 & left nest \\
\hline Bird III & 12.23 & 14.45 & 16.88 & 16.88 \\
\hline $\begin{array}{l}\text { Number of times food } \\
\text { was brought to nest }\end{array}$ & 50 & 46 & 29 & \\
\hline Weather & $\begin{array}{l}\text { Rainy } \\
\text { Rained } \\
\text { in A.M. }\end{array}$ & Rainy & $\begin{array}{l}\text { Cloudy } \\
\text { Threatening }\end{array}$ & Clear \\
\hline
\end{tabular}

When the nestlings were eight days old, although they were not well feathered, the parents coaxed them from the nest. This they accomplished by calling "Chirp, chirp" near the nest, sometimes with and sometimes without food in their mandibles, and then waiting until a nestling hopped out. As soon as the nestling approached, they retreated a few feet and then again waited. If the nestling seemed disinclined to continue following, the parents went back near it and again called "Chirp." The nestling would probably start to follow. By a continuation of this process the parents of both nests enticed the young from the homes into the surrounding grass and shrubs while they were still unable to fly, and their only method of locomotion consisted of clumsy hopping. I could now see why the young had begun to assume the position I have before mentioned. This is the preparatory position for climbing out of the nest. Since the young seemed so helpless, I several times put them back into the nest. They only screamed when I touched them and again hopped out, ready for the adventures. of the world.

II.

The Hermit Thrush.

The nest of the Hermit Thrush was about a mile from those of the Vesper Sparrows. It was on much lower ground, near a bog. The vegetation was similar, except that the trees were much taller. It was placed in a shallow depression of the sandy soil, at the bases of a dwarf honeysuckle and several tall brackens, and extended above the surface of the ground about an inch and a half. It 
was much more neatly constructed than were the sparrows' nests. The same building materials were used bracken stems and blue, grass, with the addition of a lining of pine needles. A few oak leaves on the margin helped to hide it from view, since the surrounding surface, too, was strewn with oak leaves. The nest contained four greenish blue eggs when I first discovered it.

As soon as the eggs began to hatch, I had the tent pitched and began to study this family as I had studied the sparrows. My first discovery was that I had a much shyer bird with which to deal. I sat through the first day, waiting in vain for the parents to take care of their young. Neither one came to the nest from morning till noon, nor from noon until 5 P. M. All I saw for my watching was four weak heads raised every now and then on unsteady necks, and four yellow, opened mouths close unfed. Fearing that the parents might desert the nest, I left at 5 P. M. Toward evening I returned. The nestlings were cold, and had not been fed or brooded, I believe, since I left. I had the blind removed. Since the young were warm and in good condition the next morning, I had the blind pitched a second time. This time I cut a few leafy branches and placed them over the window end, to cover up any perceptible movement across the slit. I accomplished little more the second day than I had on the first. The parents approached the nest with food, but never became quite courageous enough to enter the home. On the third day I found that the parents had decided to conduct the affairs of their household regardless of the introduction of a staring white tent right beside their nest.

I could not distinguish the parents from each other until the fifth day. I then found that one had a much grayer back, lores, and mid-tail feathers than the other. I called this the male.

Their manner of conducting their home duties was so similar to that of the sparrows that they might well have been the same family. For a while I felt that they were not such clean nestkeepers. One of the nestlings had died the second day from a rupture near the anal opening, and was left in the nest until it swarmed with ants that came to feed upon it. On the fifth day, while I was away, it and all the excrement that had been allowed to accumulate were removed. No doubt this apparent laxity was due to the birds being disturbed. From then on, at any rate, everything was kept clean. The Hermit Thrushes removed the 
excreta, ants and egg-shells just as the sparrows did. The female did most of the brooding. Neither parent did much. The female also did the greater part of the feeding. The food selected by the parents for the young consisted entirely of insects either in the larval or adult state. Katydids, grasshoppers, crickets, sawfly larvæ, robber flies, a few hairy caterpillars, and a moth or two made up their food. I noticed such a variation in the gain in weight of the different nestlings that I marked them on the head with paint in such a way as to distinguish one from the other, so that I could determine whether the parents fed impartially. Table II shows the number of times, from August 7 until August 9, that each bird was fed.

TABLE II.

FEEDING PERIOD.

Each figure in the table gives number of feedings for each period.

$\begin{array}{lccccc}\quad \text { Period of } & \text { August 7 } & \text { August } 8 & \text { August } 8 & \text { August } 9 & \\ \text { Observation } & 1: 20-3: 00 & 7: 05-11: 15 & 12: 15-3: 0 & 7: 05-10: 30 & \text { Total } \\ \text { Bird I } & 4 & 11 & 4 & 5 & 24 \\ \text { Bird II } & 5 & 12 & 2 & 10 & 29 \\ \text { Bird III } & 3 & 9 & 4 & 3 & 19 \\ \text { Total } & 12 & 32 & 10 & 18 & 72\end{array}$

Each figure in the table gives number of feedings for each period. The parents fed indiscriminately. Bird III did not receive as many feedings as the others and therefore lost a greater amount in weight. Bird II received the most feedings and his weight from August 7 to 9 shows a gradual increase. Table III shows the share each parent took in caring for the young in so far as I was able to distinguish them. I could not distinguish them until the fifth day.

Their method of approaching and leaving their nest was like that of the sparrows. The first few days neither parent gave a call when approaching, and it was only by close watching that I could tell that they had visited the nest. Often, however, they gave a deep, throaty "Cluck" when on the nest's rim. Soon they began to give a robin like "Chirp" or a "Neink, neink" call, when some distance from the nest. This was taken by the bird on the nest as a signal to leave. One day the male was having difficulty inducing 


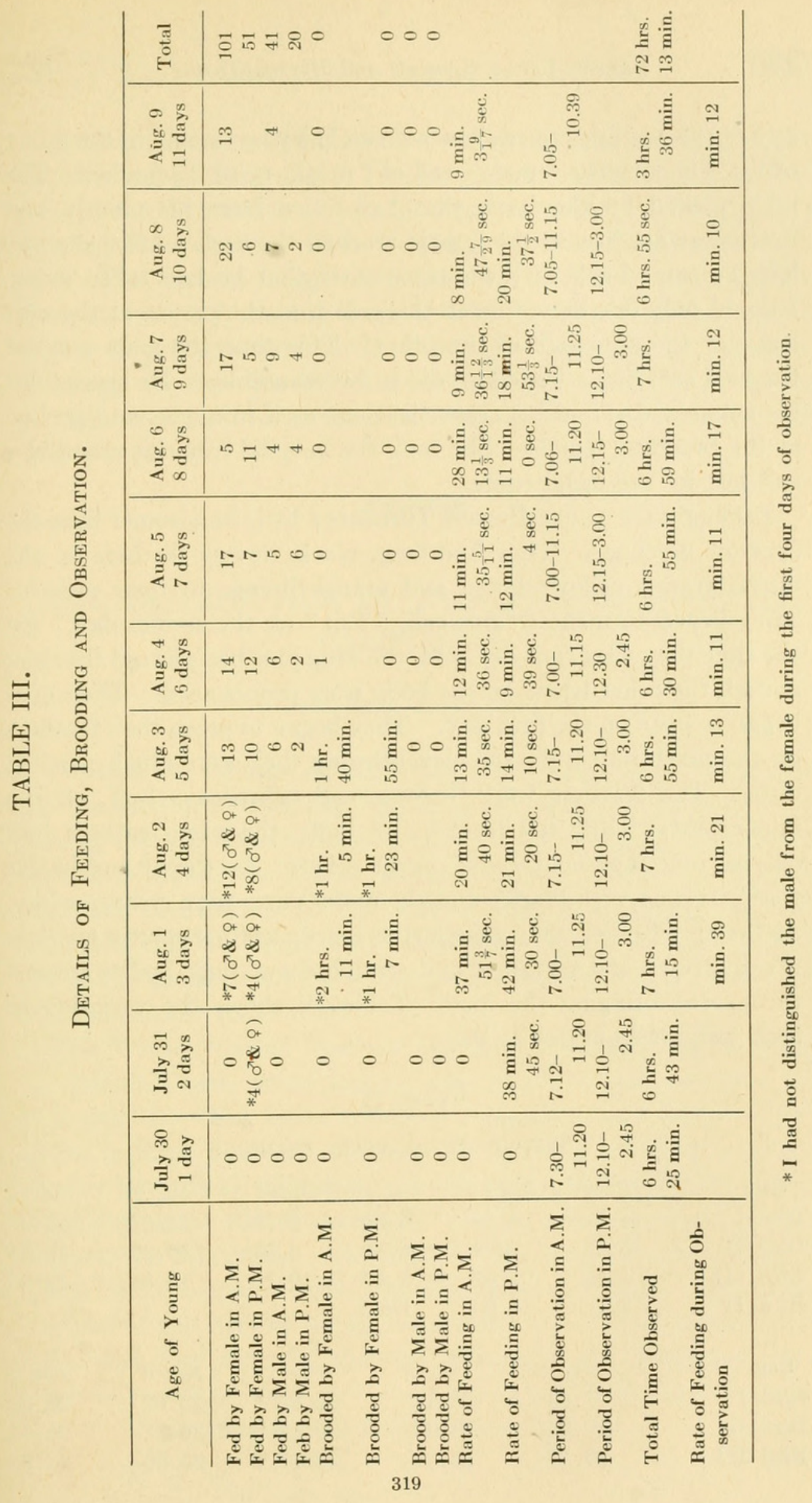


any of the nestlings to swallow a green hairy larva, and in the midst of his difficulty the female's call of "neink, neink" sounded. The male picked up the larva that had fallen from his mouth, and hurried away, just as the female reached the nest. After she had left, he came back with the same caterpillar he had taken away. I noted only one exception to this rule that the parent at the nest leave at the approach of the other. This time the male reached the nest carrying a large katydid in his mandibles. He spread out his wings and raised his crown feathers as if in anger, and pecked at the brooding female. She took the katydid from his mandibles. and left by the usual route.

I thought the young Hermit Thrushes a little handsomer than the sparrow nestlings. They had long, black, downy feathers on the dorsal tract; yellow skins; and orange linings to their mouths. They began to make a faint call, "Tsit" on the second day. By the time they were four days old, the wing pins had pierced the skin, and all the other tracts on the body were pronounced. Their eyes began to open on the fifth day. They began to preen their feathers. on the ninth day. By the eleventh day they were much mottled birds. The feathers were fuscous, and ochraceous buff, on the upper parts; their tail feathers all buff; the wing feathers buff on one vane, and ochraceous on the others; the throat and breast were streaked with black; and the under parts were creamy white. As they grew older, they were just as greedy as their coarser cousins, the sparrows, and screamed and stretched out their bodies toward the parent bringing the food. Table IV shows the variation in their weights from day to day.

TABLE IV.

WEIGHT OF YOUNG IN GRAMS.

\begin{tabular}{lrrrrrr}
\multicolumn{1}{c}{ Date } & July 30 & July 31 & Aug. 1 & Aug. 2 & Aug. 3 & Aug. 4 \\
Bird I & 4.99 & 4.80 & 6.35 & 9.72 & 14.52 & 16.25 \\
Bird II & 5.18 & 4.34 & 6.80 & 9.53 & 14.26 & 16.31 \\
Bird III & 5.83 & 5.57 & 8.42 & 10.72 & 15.81 & 18.45 \\
Bird IV & 4.7 & 4.00 & Died & & &
\end{tabular}

$\begin{array}{llllll}\text { Date } & \text { Aug. } 5 & \text { Aug. } 6 & \text { Aug. } 7 & \text { Aug. } 8 & \text { Aug. } 9 \\ \text { Bird I } & 21.63 & 23.18 & 25.95 & 23.62 & 23.62 \\ \text { Bird II } & 19.04 & 21.43 & 22.92 & 26.21 & 26.59 \\ \text { Bird III } & 20.58 & 23.28 & 29.77 & 25.56 & 23.94\end{array}$


Although it was raining on the twelfth day, the nestlings began to climb out of their nest. The parents encouragingly chirped to them, a few feet away. I put the first one back. Although I had handled it every day while weighing it, now it screamed with fear. The parents forgot their timidity and flew down angrily close to my head, making a queer clicking noise. It was useless to try to prevent these little wanderers from leaving the nest. Although weather conditions were unfavorable, and they could not fly, they had to leave. The nest cycle of twelve days had been completed.

\section{THE DISTRIBUTION OF NUTTALL'S SPARROW IN CALIFORNIA.}

BY CARL L. HUBBS.

During the months of May, June, and July, 1916, the writer was engaged in a collecting trip along the central California coast. During the trip observations were repeatedly made on Zonotrichia leucophrys nuttalli, as it soon became apparent that the peculiarly restricted distribution of this sparrow had not received the full attention that its significance deserves. These detailed records are briefly presented, as they are used to establish and justify the generalizations that follow.

This White-crowned Sparrow breeds in the humid region along the Pacific Coast, occupying an area south of that inhabited by $Z$. l. gambeli. The latter subspecies migrates southward to California in large numbers, whereas $Z$. $l$. nuttalli undertakes no extensive latitudinal migration, merely occupying a slightly wider range during the winter months than in the breeding season.

- Definite Records. - Dr. Grinnell has recorded the status of Zonotrichia leucophrys nuttalli in California as follows: "Common resident of the narrow humid coast belts"; ${ }^{1}$ "breeds south from Humboldt Bay through the San Francisco and Monterey Bay 


\section{$2 \mathrm{BHL}$ Biodiversity Heritage Library}

1918. "Home Life of the Vesper Sparrow and the Hermit Thrush." The Auk 35, 310-321. https://doi.org/10.2307/4072908.

View This Item Online: https://www.biodiversitylibrary.org/item/54099

DOI: https://doi.org/10.2307/4072908

Permalink: https://www.biodiversitylibrary.org/partpdf/90408

\section{Holding Institution}

Smithsonian Libraries

\section{Sponsored by}

Smithsonian

\section{Copyright \& Reuse}

Copyright Status: Public domain. The BHL considers that this work is no longer under copyright protection.

This document was created from content at the Biodiversity Heritage Library, the world's largest open access digital library for biodiversity literature and archives. Visit BHL at https://www.biodiversitylibrary.org. 